\title{
Cultural Adaptation, Reliability and Validity of The Pelvic Girdle Questionnaire in Pregnant
}

\section{Gebelerde Pelvik Kuşak Anketinin Kültürel Adaptasyonu, Güvenilirliği ve Geçerliği}

\author{
Gül Deniz Yilmaz Yelvar ${ }^{1}, \underline{\text { Yasemin Çırak }}^{2}$, $\underline{\text { Yasemin Parlak Demir }}^{3}$, Emine Seda Türkyılmaz $^{4}$ \\ ${ }^{1}$ Kıbrıs İlim Üniversitesi Sağlık Bilimleri Yüksekokulu Fizyoterapi ve Rehabilitasyon Bölümü, Girne \\ ${ }^{2}$ İstinye Üniversitesi Sağlık Bilimleri Fakültesi Fizyoterapi ve Rehabilitasyon Bölümü, İstanbul \\ 3Bağımsız Araştırmacı, Ankara \\ ${ }^{4}$ Hacettepe Üniversitesi Sağlık Bilimleri Enstitüsü, Ankara
}

\begin{abstract}
Objectives: The aims of this study were to translate the Pelvic Girdle Questionnaire (PGQ) to Turkish and to assess its test-retest reliability and validity in pregnant women.

Materials and Methods: One hundred and thirty-five pregnant with pelvic girdle pain were recruited in the study. Visual analog scale was used to evaluate pain intensity, PGQ for condition-specific health related quality of life, Nottingham Health Profile for health-related quality of life, Oswestry Disability Index for disability level, The guidelines for cross-cultural adaptation in PGQ was used.

Results: A total of 135 pregnant with a mean age of the $30 \pm 4.77$ years included in the study. Interclass correlation coefficient score for test-retest reliability was 0.972 (95\% CI= 0.968-0.977) for PGQ activity subscale, 0.910 ( $95 \% \mathrm{CI}=0.905-0.915)$ for PGQ symptom subscale and $0.979(95 \% \mathrm{CI}=0.975-0.983)$ for PGQ total.

Conclusion: The study demonstrated that Turkish version of PGQ is a valid and reliable tool for measuring both disability and symptom and good psychometric properties in Turkish speaking pregnants with pelvic girdle pain.

Keywords: Pelvic girdle pain, Turkish version, reliability, validity, cultural adaptation, pregnancy
\end{abstract}

\section{$\ddot{O} \mathbf{z}$}

Amaç: Bu çalışmanın amacı gebe kadınlarda Pelvik Kuşak Anketi'ni (PKA) Türkçe'ye çevirmek ve testtekrar test güvenilirliği ve geçerliğini değerlendirmekti.

Materyal ve Metot: Çalıșmaya pelvik kuşak ağrısı olan 135 gebe alındı. Ağrı şiddetini değerlendirmek için görsel analog skalası, duruma özel sağlık ile ilgili yaşam kalitesine için PKA, sağlıkla ilgili yaşam kalitesi için Nottingham Sağlık Profili, özürlülük düzeyi için Oswestry Özürlülük İndeksi, PKA'da kültürlerarası uyum için kılavuzlar kullanılmıștır.

Bulgular: Çalışmaya yaş ortalaması $30 \pm 4,77$ olan 135 gebe dahil edildi. Test-tekrar test güvenirliği için sınıflar arası korelasyon katsayısı puanı, PKA aktivite alt boyutu için o, 972 (\% $95 \mathrm{CI}=0$,968-o,977), PKA semptom alt boyutu için o,910 (\% $95 \mathrm{CI}=0$ 0,905-0,915) ve PKA toplam için o,979 (\% $95 \mathrm{CI}=0$,905-0,915) olarak bulundu.

Sonuç: Çalışma, pelvik kuşak ağrısı olan Türkçe konuşan gebelerde PKA'nin Türkçe versiyonunun hem sakatlığı hem de semptomu ölçmek için geçerli ve güvenilir bir araç olduğunu ve iyi psikometrik özelliklere sahip olduğunu göstermiştir.

Anahtar Kelimeler: Pelvik kuşak ağrısı, Türkçe versiyon, geçerlik, güvenirlik, kültürel adaptasyon, gebelik

Yazıșma Adresi / Correspondence:

Gül Deniz Yılmaz Yelvar

Kıbrıs İlim Üniversitesi Sağlık Bilimleri Yüksekokulu Fizyoterapi ve Rehabilitasyon Bölümü, Girne

e-mail: guldenizy@yahoo.com

Date of submission: 26.03.2019

Date of admission: 09.09.2019 


\section{Introduction}

Pelvic girdle pain (PGP) is a common condition referring to pain in one or both sacroiliac joints, the symphysis pubis, the gluteal region or all of the above-mentioned regions. ${ }^{1}$ The pathophysiology of PGP may be related to a combination of both biomechanical and hormonal factors. Relaxin is a polypeptide hormone causing laxity of the connective tissue, resulting in the widening and separation of the symphysis pubis during pregnancy. In addition, there is increased laxity in the sacroiliac joint, which acts as a stabilizer during load transfer from the trunk to the legs, increased spinal curvature during the pregnancy and changed center of gravity anteriorly and superiorally.2,3,4 The term, 'pregnancy related' is used in the literature because the symptoms begin during or after pregnancy. Approximately $45 \%$ of all pregnant women and $25 \%$ of all postpartum women experience PGP. 5 The pain symptoms improve a few weeks or months after delivery, but $18.5 \%$ of women report persistent pain and $3.0 \%$ report pelvic girdle syndrome. ${ }^{6}$

For the evaluation of PGP, adequate outcome measures are required. The Pelvic Girdle Questionnaire (PGQ), the first condition-specific outcome measure designed to assess the aspects of the quality of life in PGP patients, was originally developed for use both during pregnancy and postpartum and tested on Norwegian women. Traditionally, clinical measurements have generally been based on the perspective of the clinician. The PGQ enables information gathering about the patients' conditions from their perspective. ${ }^{7}$

Most functional questionnaires are developed in the English language; however, measures should be specifically designed for non-English speaking countries. Therefore, large, multicentre, multinational trials are needed. In contrast, a questionnaire previously developed in another language can be used providing that cultural adaptations are made. 8 Consequently, internationally accepted tools for functional assessment have been adapted and used, particularly in clinical research.9,10

To the best of our knowledge, there is no questionnaire for assessing pelvic girdle pain in Turkey. The aims of this study were to translate the Pelvic Girdle Questionnaire into Turkish and to evaluate its test-retest reliability and construct validity.

\section{Materials and Methods}

\section{Participants}

The study was performed at Turgut Özal University School of Physiotherapy and Rehabilitation. Women with back pain were referred by the obstetrician to the physiotherapy and rehabilitation unit and clinically examined by the same physical therapist using the recommended inclusion criteria ${ }^{2}$ as outlined in Table 1 . The exclusion criteria were as follows: being illiterate, having locomotor system disease and a history of fracture or spinal, pelvic or lower extremity surgery. The study was approved by the University's Human Investigation Committee (2012-04), and all participants read and signed the informed consent form prior to enrolment in the study.

\section{Instruments}

Pain intensity was measured on a visual analogue scale (VAS; o-10o mm). ${ }^{11}$ 
The original Pelvic Girdle Questionnaire (PGQ) was published in 2011 and consisted of 25 items including activity and symptom subscales. Each item was scored on a fourpoint response scale that ranged from no problem at all (score o) to a large extent (score 3). The scores were summarized and recalculated to percentage scores from o (no problem at all) to 100 (to a large extent), where 100 was the worst possible score. For the total PGQ the scores are summarized, then divided by 75 and multiplied with 100 to get the percentage. For the subscale activity the scores are summarized and divided by 60 and for the subscale symptom the scores are summarized and divided by 15, and multiplied with 100. ${ }^{7}$

The original Oswestry Disability Index (ODI) was developed in a specialist referral clinic for patients with chronic low back pain. ${ }^{12}$ The ODI included 10 items (pain intensity, personal hygiene, lifting, walking, sitting, standing, sleeping, sexual activity, social activity and travelling) and was scored on a 6-point Likert Scale. The scores we re summarized and recalculated to percentage scores from o to 100, where 100 was the worst possible disability. We used the items in the Turkish version developed by Yakut et al. and found good comprehensibility, internal consistency and validity for the assessment of disability in patients with low back pain. ${ }^{13}$

General health was assessed using the Nottingham Health Profile (NHP) originally developed in the Department of Public Health at the University of Nottingham. ${ }^{14}$ Cultural adaptation of the Turkish version and psychometric properties were developed by Kucukdeveci et al. The NHP includes 38 items and 6 subscales: energy level, pain, physical activity, sleep, emotional reaction and social isolation. The total score of each subscale ranges from o to 100. The adaptation of the NHP into Turkish was found to be successful. ${ }^{15}$

\section{Translation of the PGQ}

We used the guidelines for cross-cultural adaptation of the translation process. ${ }^{16}$ Britt Stuge from the Department of Orthopaedics in Oslo University Hospital, Norway was contacted via mail to determine whether there were any attempts in progress to develop the Turkish version of the questionnaire. We established a translation team, which consisted of 2 bilingual physiotherapists, 2 native Turkish-speaking physiotherapists and 1 bilingual native English-speaking teacher whose qualifications included a university degree in English. The original PGQ was translated from English to Turkish independently and separately by native Turkish-speaking physiotherapists and a draft Turkish version was produced. The draft translation was then given to the native English speaker to translate back to English. The native speaker was blind to the original version of the questionnaire and to the purpose of the study. The content of the original and the back-translated English versions were compared, and differences were noted. The team reviewed and compared the original version and reversedtranslated the English version to detect errors of interpretation and nuances that might have been missed. The original English, Turkish and reverse-translated English versions and a synthesis of translation differences were discussed by the translation team. The translation team reached a consensus on the PGQ regarding linguistic imprecision and cultural differences. Another stage of the translation process is a test of the pre-final version. A total of 30 volunteer patients with PGP were included in the pilot study to determine any misunderstandings and deviations in the translation. The comprehensibility and acceptability of the translation were tested item by item. All of 
the participants responded that the scale was easy to understand. The final version of the PGQ was produced by consensus and is described in appendix 1.

\section{Statistical analysis}

All data analyses were performed using SPSS (Statistical Package for the Social Sciences) 15.0 for Windows. For investigating normality of the distribution of continuous variables, the Kolmogorov-Smirnov test was used. The descriptive statistics were expressed as the mean \pm SD for continuous variables and as the number of patients and percentage (\%) for categorical variables.

Construct validity of the Turkish version of the instrument was measured by comparing the VAS, ODI and NHP7. This relation was measured using Pearson's correlation analysis with the probability error of $\mathrm{p}<0.05$. The construct validity coefficients were accepted as follows: $r \geq 0.81-1.0$ as excellent, $0.61-0.80$ very good, $0.41-0.60$ good, $0.21-0.40$ fair and o-0.20 poor. ${ }^{17}$

For reliability, internal consistency and test-retest reliability were calculated. Testretest reliability is a measure of stability when the same test is applied to the same subjects at two points in time. The appropriate interval length depends on the stability of the variables. In this study, 7 days was used as a time interval. Test-retest reliability was determined using the intraclass correlation coefficient (ICC). The internal consistency of a scale is a measure of scale homogeneity. The coefficient of internal consistency is calculated with Cronbach's alpha. ICC can vary from 0.00 to 1.00 , in which values of $0.60-0.80$ are regarded as evidence of good consistency with those $>0.80$ indicating excellent consistency. Portney and Watkins claim that for most clinical measurements, reliability should be $>0.90$ to ensure reasonable validity. ${ }^{18}$

\section{Results}

A total of 151 pregnant women ranging from 20 to 40 years of age attended and a total of 135 pregnant women with a mean age of $30 \pm 4.77$ years were included in the study. The non-response rate was $11 \%$ and the flowchart of the study is shown in Figure 1. Table 1 shows the patients' demographic and clinical characteristics.
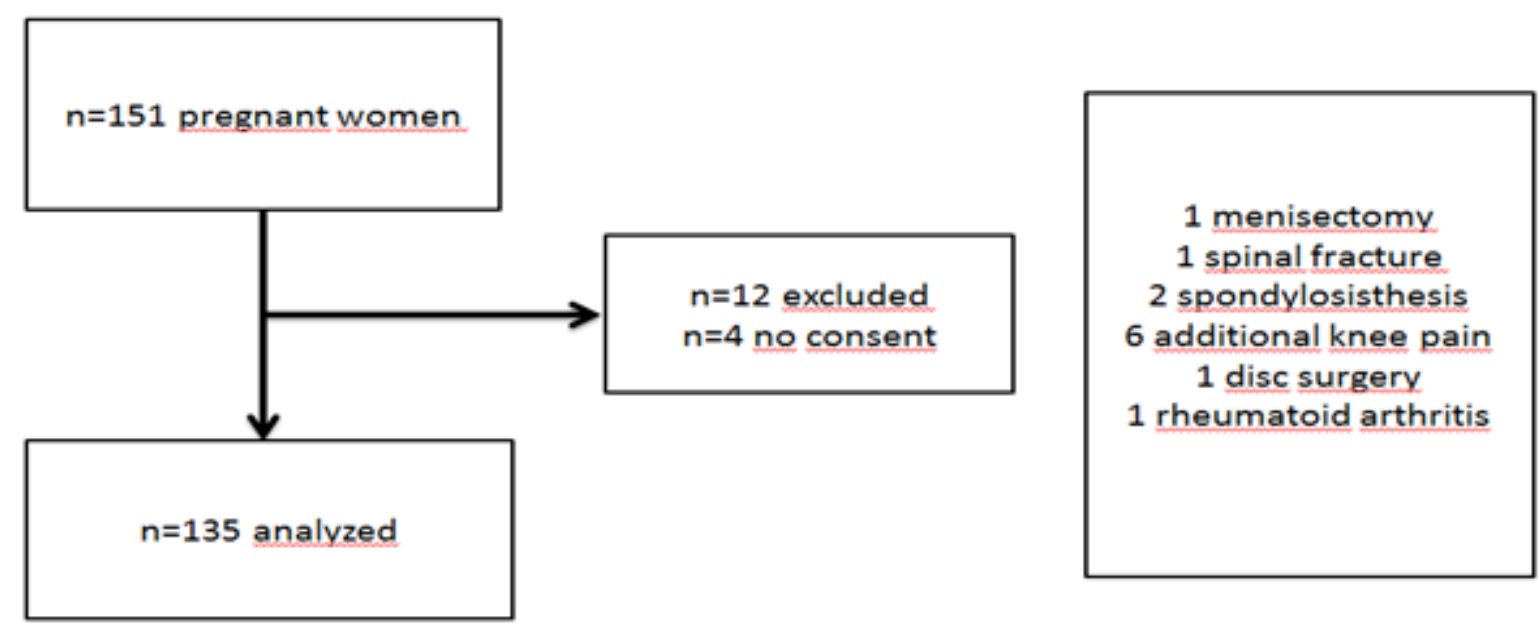

Figure 1. Enrollment of the study 
Table 1. Inclusion criteria of the study

Pain located distal, lateral or both in relation to the L5-S1 area

Pain in buttocks, symphysis or both

Tests:

- Posterior Pelvic Pain Provocation Test,

- Active Straight Leg Raising Test,

- pain provocation of the long dorsal sacroiliac ligament,

- pain provocation of the symphysis by palpation and

- pain provocation by a modified Trendelenburg test

The results of the Posterior Pelvic Pain Provocation Test or the Active Straight Leg Raising Test had to be positive on the right side, left side, or both, and the results of at least 1 of the other 3 tests had to be positive

The range of the 'if item-deleted $\alpha$ values' was $0.869-0.882$ for the PGQ activity subscale and $0.600-0.714$ for the PGQ symptom subscale in the analysis of internal consistency reliability (Table 2 ).

Table 2. Demographic and Clinical Characteristics of the Pregnant Women $(n=135)$

\begin{tabular}{|c|c|}
\hline Characteristic & Value \\
\hline Age, years, $m \pm s d$ & $30.00 \pm 4.77$ \\
\hline Gestational week, $\mathrm{m} \pm \mathrm{sd}$ & $22.60 \pm 8.89$ \\
\hline BMI, $\mathbf{k g} / \mathrm{m}^{2}, \mathrm{~m} \pm \mathrm{sd}$ & $25.03 \pm 3.52$ \\
\hline $\begin{array}{l}\text { Weight gaining with pregnancy, } \mathrm{kg}, \\
\mathrm{m} \pm \mathrm{sd}\end{array}$ & $7.20 \pm 4.81$ \\
\hline $\begin{array}{l}\text { Number of pregnancies, } \mathrm{n}(\%) \\
1 \\
2 \\
3 \text { or more }\end{array}$ & $\begin{array}{l}79(58.52) \\
31(22.96) \\
25(18.52)\end{array}$ \\
\hline $\begin{array}{l}\text { Pain localization, } \mathrm{n}(\%) \\
\text { Pain located at symphysis pubis } \\
\text { Pain located at posterior } \\
\text { Pain located at both of them }\end{array}$ & $\begin{array}{l}23(17.04) \\
74(54.81) \\
38(28.15) \\
\end{array}$ \\
\hline Pain duration, month, $\mathrm{m} \pm \mathrm{sd}$ & $1.75 \pm 0.45$ \\
\hline Current smoker, n (\%) & $27(20)$ \\
\hline $\begin{array}{l}\text { Educational status, n (\%) } \\
\text { Primary-secondary school } \\
\text { High school } \\
\text { University }\end{array}$ & $\begin{array}{l}16(11.85) \\
40(29.63) \\
79(58.52)\end{array}$ \\
\hline $\begin{array}{l}\text { Doing exercise, } \mathrm{n}(\%) \\
\text { Yes } \\
\text { No }\end{array}$ & $\begin{array}{l}47(34.82) \\
88(65.18)\end{array}$ \\
\hline
\end{tabular}

Abbreviations: BMI, body mass index; m, mean; SD, Standard deviation. 
Cronbach's $\alpha$ coefficients were 0.882 for the PGQ activity subscale, 0.714 for the PGQ symptom subscale and 0.894 for the total PGQ in the analysis of scale reliability.

For reliability, all of the participant were re-evaluated in terms of inclusion criteria after 1 week later and seen that all participants had pelvic girdle pain. Thus we applied the PGQ to the same subjects. The ICC score for test-retest reliability was 0.972 (95\% $\mathrm{CI}=0.968-0.977)$ for the PGQ activity subscale, $0.910\left(95 \% \mathrm{CI}=0.905^{-0.915}\right)$ for the PGQ symptom subscale and $0.979\left(95 \% \mathrm{CI}=0.975^{-0.983}\right)$ for the total PGQ (Table 3$)$.

Table 3. Interclass correlation analysis of PGQ

\begin{tabular}{|c|c|c|c|}
\hline Scale/Item & $\begin{array}{l}\text { Item-total } \\
\text { correlation }\end{array}$ & $\begin{array}{c}\alpha \\
\text { (If Item } \\
\text { Deleted) }\end{array}$ & $\begin{array}{c}\alpha \\
(\text { Overall })\end{array}$ \\
\hline $\begin{array}{l}\text { Pelvic Girdle Questionnaire activity } \\
\text { subscale score }(0-3)\end{array}$ & & & 0.882 \\
\hline 1. $\quad$ Dress yourself & 0.436 & 0.879 & \\
\hline 2. Stand for less than $10 \mathrm{~min}$ & 0.436 & 0.879 & \\
\hline 3. Stand for more than $60 \mathrm{~min}$ & 0.493 & 0.877 & \\
\hline 4. Bend down & 0.400 & 0.880 & \\
\hline 5. Sit for less than $10 \mathrm{~min}$ & 0.458 & 0.878 & \\
\hline 6. Sit for more than $60 \mathrm{~min}$ & 0.653 & 0.871 & \\
\hline 7. Walk for less than $10 \mathrm{~min}$ & 0.316 & 0.882 & \\
\hline 8. Walk for more than 60 min & 0.644 & 0.874 & \\
\hline 9. Climb stairs & 0.700 & 0.870 & \\
\hline 10. Do housework & 0.494 & 0.877 & \\
\hline 11. Carry light objects & 0.473 & 0.878 & \\
\hline 12. Carry heavy objects & 0.312 & 0.882 & \\
\hline 13. Get up/sit down & 0.722 & 0.869 & \\
\hline 14. Push a shopping cart & 0.571 & 0.874 & \\
\hline 15. Run & 0.327 & 0.882 & \\
\hline 16. Carry out sporting activities & 0.237 & 0.882 & \\
\hline 17. Lie down & 0.633 & 0.872 & \\
\hline 18. Roll over in bed & 0.551 & 0.875 & \\
\hline 19. Have a normal sex life & 0.499 & 0.877 & \\
\hline 20. Push something with 1 foot & 0.527 & 0.876 & \\
\hline $\begin{array}{l}\text { Pelvic Girdle Questionnaire symptom } \\
\text { subscale score }(0-3)\end{array}$ & & & 0.714 \\
\hline 1. Pain in the morning & 0.400 & 0.714 & \\
\hline 2. Pain in the evening & 0.430 & 0.682 & \\
\hline $\begin{array}{l}\text { 3. Has your leg/have your legs given } \\
\text { way? }\end{array}$ & 0.530 & 0.641 & \\
\hline 4. Do you do things more slowly? & 0.628 & 0.600 & \\
\hline 5. Is your sleep interrupted? & 0.474 & 0.665 & \\
\hline
\end{tabular}


According to Pearson's correlation analysis, the $\mathrm{r}$ value was $0.975(\mathrm{p}<0.001)$ for the PGQ activity subscale, 0.912 ( $\mathrm{p}<0.001$ ) for the PGQ symptom subscale and 0.981 for the total PGQ (Table 4).

Table 4. Reliability of the Pelvic Girdle Questionnaire

\begin{tabular}{|l|c|}
\hline Internal consistency: Cronbach's $\boldsymbol{\alpha}(\mathbf{N}=\mathbf{1 3 5})$ & Value \\
\hline PGQ Activity Subscale & 0.714 \\
\hline PGQ Symptom Subscale & 0.882 \\
\hline PGQ Total Scale & 0.894 \\
\hline Test-retest reliability: ICC & \\
\hline PGQ Activity Subscale & $0.972(95 \% \mathrm{CI}=0.968-0.977)$ \\
\hline PGQ Symptom Subscale & $0.910\left(95 \% \mathrm{CI}=0.905^{-0.915}\right)$ \\
\hline PGQ Total Scale & $0.979(95 \% \mathrm{CI}=0.975-0.983)$ \\
\hline Test-retest reliability: correlation, $\mathbf{r}$ & $\mathbf{0 . 9 7 5 ^ { * * }}$ \\
\hline PGQ Activity Subscale & $\mathbf{0 . 9 1 2}$ \\
\hline PGQ Symptom Subscale & $\mathbf{0 . 9 8 1}^{\text {** }}$ \\
\hline PGQ Total Scale & \\
\hline
\end{tabular}

Abbreviations: ICC, Intraclass correlation coefficient. ${ }^{* *}, \mathbf{p}<\mathbf{0 . 0 0 1}$

When the correlation between the PGQ and the ODI was investigated, the $\mathrm{r}$ value was o.693 (a good correlation, p<0.001) for the PGQ activity subscale, 0.772 (a very good correlation, $\mathrm{p}<0.001$ ) for the PGQ symptom subscale and 0.800 (and excellent correlation, $\mathrm{p}<0.001$ ) for the total PGQ. When the relation between the total PGQ and total NHP was investigated, the $r$ value was 0.406 (a moderate correlation, $\mathrm{p}=0.002$ ) for the PGQ activity subscale and 0.603 (a good correlation, $\mathrm{p}<0.001$ ) and 0.507 (a good correlation, $\mathrm{p}<\mathrm{0.001}$ ) for the total PGQ. The correlation coefficient between PGQ and pain severity was 0.522 (a moderate correlation, $\mathrm{p}<0.001$ ) for the PGQ activity subscale, 0.585 (a moderate correlation, $\mathrm{p}<0.001$ ) for the PGQ symptom subscale and 0.645 (a good correlation, $\mathrm{p}<0.001$ ) for the total PGQ. These results demonstrated construct validity of the Turkish version of the PGQ. The results of the tests for validity are shown in Table 5. Also, mean and standard deviation values of the questionnaire scores are shown in Table 6.

\section{Discussion}

Our study demonstrated that the Turkish version of the PGQ is a valid and reliable instrument for measuring both disability and symptoms in Turkish speaking pregnant women with PGP. The questionnaire is simple, takes just 3 min to complete and can be easily incorporated into epidemiological studies and clinical research. The questionnaire also has good psychometric properties.

Adequate translation procedures are needed to achieve cross-cultural equivalence when translating participant-reported outcome measures. The results of reliability and validity testing are consistent with previous studies, which show that our translation procedure was adequate. 
Table 5. Validity of the Pelvic Girdle Questionnaire

\begin{tabular}{|c|c|c|c|c|}
\hline & & $\begin{array}{l}\text { PGQ Activity } \\
\text { Subscale }\end{array}$ & $\begin{array}{c}\text { PGQ } \\
\text { Symptom } \\
\text { Subscale }\end{array}$ & $\begin{array}{l}\text { PGQ Total } \\
\text { Scale }\end{array}$ \\
\hline \multirow{2}{*}{ NHP pain } & $\mathbf{r}$ & $0.543^{* *}$ & $0.546^{* *}$ & $0.610^{* *}$ \\
\hline & $\mathbf{p}$ & $<0.001$ & $<\mathbf{0 . 0 0 1}$ & $<0.001$ \\
\hline \multirow{2}{*}{ NHP sleep } & $\mathbf{r}$ & 0.138 & $0.472^{* *}$ & 0.231 \\
\hline & $\mathbf{p}$ & 0.31 & $<0.001$ & 0.076 \\
\hline \multirow{2}{*}{ NHP energy } & $\mathbf{r}$ & $0.341^{*}$ & $0.396^{*}$ & $0.414^{*}$ \\
\hline & $\mathbf{p}$ & 0.01 & 0.002 & 0.001 \\
\hline \multirow{2}{*}{ NHP social isolation } & $\mathbf{r}$ & 0.068 & $0.269^{*}$ & 0.132 \\
\hline & $\mathbf{p}$ & 0.619 & 0.038 & 0.315 \\
\hline \multirow{2}{*}{ NHP emotional status } & $\mathbf{r}$ & $0.298^{*}$ & $0.339^{*}$ & $0.296^{*}$ \\
\hline & $\mathbf{p}$ & 0.026 & 0.008 & 0.022 \\
\hline \multirow{2}{*}{ NHP Physical mobility } & $\mathbf{r}$ & $0.370^{*}$ & $0.606^{* *}$ & $0.499^{* *}$ \\
\hline & $\mathbf{p}$ & 0.005 & $<0.001$ & $<0.001$ \\
\hline \multirow{2}{*}{ NHP total } & $\mathbf{r}$ & $0.406^{*}$ & $0.603^{* *}$ & $0.507^{* *}$ \\
\hline & $\mathbf{p}$ & 0.002 & $<0.001$ & $<0.001$ \\
\hline \multirow{2}{*}{$\begin{array}{l}\text { Oswestry Disability Index } \\
\text { score }\end{array}$} & $\mathbf{r}$ & $0.693^{* *}$ & $0.772^{* *}$ & $0.800^{* *}$ \\
\hline & $\mathbf{p}$ & $<0.001$ & $<0.001$ & $<\mathbf{0 . 0 0 1}$ \\
\hline \multirow{2}{*}{ Pain Severity-VAS (o-10) } & $\mathbf{r}$ & $0.5^{22}{ }^{* *}$ & $0.585^{* *}$ & $0.645^{* *}$ \\
\hline & $\mathbf{p}$ & $<0.001$ & $<0.001$ & $<0.001$ \\
\hline
\end{tabular}

Abbreviations: r: Pearson's correlation coefficients; NHP:Nottingham Health Profile; VAS: Visual Analog Scale; ${ }^{* *} \mathrm{p}<0.001 ;{ }^{*} \mathrm{p}<0.05$

Table 6. Results of Pelvic Girdle Questionnaire, Nottingham Health Profile, Oswestry Disability Index and Visual Analog Scale Scores

\begin{tabular}{|l|c|c|}
\hline & Minimum-Maximum & X \pm SD \\
\hline PGQ Activity Subscale & $11.11-78.33$ & $44.46 \pm 17.81$ \\
\hline PGQ Symptom Subscale & $0-93.33$ & $41.89 \pm 19.95$ \\
\hline PGQ Total Scale & $11-80$ & $43.72 \pm 17.23$ \\
\hline NHP pain & $0-100$ & $42.04 \pm 26.88$ \\
\hline NHP sleep & $0-77.63$ & $19.94 \pm 22.70$ \\
\hline NHP energy & $0-100$ & $50.86 \pm 35.99$ \\
\hline NHP social isolation & $0-100$ & $12.56 \pm 25.30$ \\
\hline NHP emotional status & $0-100$ & $24.19 \pm 25.12$ \\
\hline NHP Physical mobility & $0-87.31$ & $38.54 \pm 13.67$ \\
\hline NHP total & $17.71-432.1$ & $185.36 \pm 105.81$ \\
\hline Oswestry Disability Index score & $2-70$ & $29.77 \pm 13.85$ \\
\hline Pain Severity-VAS (o-10) & $2-10$ & $5.45 \pm 1.58$ \\
\hline
\end{tabular}

X. Mean; SD. Standard Deviation; PGQ. Pelvic Girdle Questionnaire; NHP. Nottingham Health Profile; VAS. Visuel Analog Scale 
In our study, reliability determined by internal consistency was measured by Cronbach's $\alpha$ values. ICC can vary from 0.00 to 1.00 , in which the values of $0.60-0.80$ are regarded as evidence of good reliability with those $>0.80$ indicating excellent reliability. Portney and Watkins claim that for most clinical measurements, reliability should be $>0.90$ to ensure reasonable validity. ${ }^{18}$ Stuge, who developed the questionnaire, reported Cronbach $\alpha$ coefficients of 0.93 for the PGQ activity subscale and 0.91 for the PGQ symptom subscale. ${ }^{7}$ In our study, ICCs were $>0.90$ and reliability was >0.90. We found an ICC of 0.97 for the activity subscale, 0.91 for the symptom subscale and 0.98 for the total. The results showed that PGQ is a reliable tool for Turkish speaking patients with PGP.

Grotle, who examined the internal consistency, test-retest reliability and construct validity of instruments, conducted the study concerning psychometric properties of the PGQ, ODI, Disability Rating Index, Fear-Avoidance Beliefs Questionnaire activity subscale, Pain Catastrophizing Scale and 36-Item Short-Form Health Survey questionnaire to evaluate validity. ${ }^{11}$ In our study, we used the VAS, ODI and NHP to assess construct validity of the PGQ. We found a good correlation between the PGQ and VAS $(r=0.645)$, an excellent correlation between the PGQ and ODI $(r=0.800)$ and a moderate correlation between the PGQ and NHP $(r=0.406)$.

At the end of the translation process, there was no need to change any words or sentences in the Turkish version. Therefore, we concluded that this questionnaire was easily understandable to the Turkish population.

The limitation of this study was that only pregnant women were included the study. Future studies should be performed with postpartum women, because PGP occurs in both pregnant and postpartum women.

This study led to use the condition-specific, reliable, valid, easily understandable questionnaire to assess Turkish speaking pregnant women with PGP and in clinical research in a Turkish population.

The authors contributed to the study as following

GD Yilmaz Yelvar: Project development, Data Collection, Manuscript writing

Y Cirak: Project development, Data analysis

Y Parlak Demir: Project development

ES Turkyilmaz: Data Collection

The authors declare that they have no conflict of interests. This study was not funded by any institution. 


\section{Appendix}

\section{PELVIKK KUŞAK ANKETI}

Pelvik kuşak ağrısı nedeniyle aşağıda listelenen aktiviteleri gerçekleştirmeyi ne ölçüde sorunlu bulursunuz? Her bir aktivite için bugün nasıl olduğunuzu tanımlayan en iyi kutuyu ișaretleyin

\begin{tabular}{|c|c|c|c|c|}
\hline $\begin{array}{l}\text { Pelvik kușak ağrınız } \\
\text { nedeniyle sizin için ne kadar } \\
\text { sorunlu }\end{array}$ & $\operatorname{Hiç}(\mathbf{o})$ & $\begin{array}{l}\text { Küçük } \\
\text { bir } \\
\text { oranda } \\
(1)\end{array}$ & $\begin{array}{l}\text { Bir } \\
\text { dereceye } \\
\text { kadar (2) }\end{array}$ & $\begin{array}{l}\text { Büyüik } \\
\text { ölçüde } \\
\text { (3) }\end{array}$ \\
\hline \multicolumn{5}{|l|}{ 1.Kendi bașınıza giyinmek } \\
\hline \multicolumn{5}{|l|}{$\begin{array}{l}\text { 2.10 dk.dan daha az ayakta } \\
\text { durmak }\end{array}$} \\
\hline \multicolumn{5}{|l|}{$\begin{array}{l}\text { 3.6o dk.dan daha fazla ayakta } \\
\text { durmak }\end{array}$} \\
\hline \multicolumn{5}{|l|}{ 4.Yere eğilmek } \\
\hline \multicolumn{5}{|l|}{ 5.10 dk.dan daha az oturmak } \\
\hline \multicolumn{5}{|l|}{ 6.6o dk.dan daha fazla oturmak } \\
\hline \multicolumn{5}{|l|}{ 7.10 dk.dan daha az yürümek } \\
\hline \multicolumn{5}{|l|}{ 8.6o dk.dan daha fazla yürümek } \\
\hline \multicolumn{5}{|l|}{ 9.Merdiven çıkmak } \\
\hline \multicolumn{5}{|l|}{ 10.Evişi yapmak } \\
\hline \multicolumn{5}{|l|}{ 11. Hafif objeler taşımak } \\
\hline \multicolumn{5}{|l|}{ 12.Ağır objeler taşımak } \\
\hline \multicolumn{5}{|l|}{ 13.Kalkmak/oturmak } \\
\hline \multicolumn{5}{|l|}{ 14.Alışveriş arabasını itmek } \\
\hline \multicolumn{5}{|l|}{ 15.Koşmak } \\
\hline \multicolumn{5}{|l|}{ 16.Spor aktiviteleri yapmak* } \\
\hline \multicolumn{5}{|l|}{ 17.Yatmak } \\
\hline \multicolumn{5}{|l|}{ 18.Yatakta dönmek } \\
\hline \multicolumn{5}{|l|}{$\begin{array}{l}\text { 19.Normal bir cinsel hayata sahip } \\
\text { olmak* }^{*}\end{array}$} \\
\hline 20.Tek ayakla bir șeyleri itmek & & & & \\
\hline
\end{tabular}

*Uygun değilse sağdaki kutuyu ișaretleyin

\begin{tabular}{|l|c|c|c|c|}
\hline $\begin{array}{l}\text { Ne kadar ağrı } \\
\text { hissediyorsunuz }\end{array}$ & Hiç (o) & Biraz (1) & Orta (2) & $\begin{array}{c}\text { Oldukça } \\
\text { (3) }\end{array}$ \\
\hline 21.Sabah & & & & \\
\hline 22.Akşam & Hiç(o) & $\begin{array}{c}\text { Küçük } \\
\text { bir } \\
\text { oranda } \\
\text { Pelvik kuşak ağrısı yüzünden } \\
\text { ne ölçüde, }\end{array}$ & $\begin{array}{c}\text { Bir } \\
\text { dereceye } \\
\text { kadar (2) }\end{array}$ & $\begin{array}{c}\text { Büyük } \\
\text { ölçude } \\
\text { (3) }\end{array}$ \\
\hline $\begin{array}{l}\text { 23.Bacak/bacaklarınızda } \\
\text { boşalma hissi oluyor }\end{array}$ & & & & \\
\hline $\begin{array}{l}\text { 24.Bir şeyleri çok yavaş } \\
\text { yapıyorsunuz }\end{array}$ & & & & \\
\hline 25.Uykunuz bölünüyor & & & \\
\hline
\end{tabular}




\section{References}

1. Vermani E, Mittal R, Weeks A. Pelvic girdle pain and low back pain in pregnancy: a review. Pain Pract 2010;10:60-71.

2. Vleeming A, Albert HB, Ostgaard HC, Sturesson B, Stuge B. European guidelines for the diagnosis and treatment of pelvic girdle pain. Eur Spine J 2008;17:794-819.

3. Yoo H, Shin D, Song C. Changes in the spinal curvature, degree of pain, balance ability, and gait ability according to pregnancy period in pregnant and nonpregnant women. J Phys Ther Sci 2015;27:279-84

4. Takeda K, Shimizu K, Imura M. Changes in balance strategy in the third trimester. J Phys Ther Sci 2015;27:1813-7.

5. Wu WH, Meijer OG, Uegaki K, et.al. Pregnancy-related pelvic girdle pain (PPP), I: Terminology, clinical presentation, and prevalence. Eur Spine J 2004;13:575-89.

6. Bjelland EK, Stuge B, Engdahl B, Eberhard-Gran M. The effect of emotional distress on persistent pelvic girdle pain after delivery: a longitudinal population study. BJOG 2013;120:32-40.

7. Stuge B, Garratt A, Krogstad Jenssen H, Grotle M. The pelvic girdle questionnaire: a conditionspecific instrument for assessing activity limitations and symptoms in people with pelvic girdle pain. Phys Ther 2011;91:1096-108.

8. Guillemin F, Bombardier C, Beaton D. Cross-cultural adaptation of health-related quality of life measures: literature review and proposed guidelines. J Clin Epidemiol 1993;46:1417-32.

9. Gul ED, Yilmaz O, Bodur H. Reliability and validity of the Turkish version of the knee injury and osteoarthritis outcome score-physical function short-form (KOOS-PS). J Back Musculoskelet Rehabil 2013;26:461-6.

10. Melikoglu MA, Kocabas H, Sezer I, Bilgilisoy M, Tuncer T. Validation of the Turkish version of the Quebec back pain disability scale for patients with low back pain. Spine (Phila Pa 1976) 2009;34:219-24.

11. Grotle M, Garratt AM, Krogstad Jenssen H, Stuge B. Reliability and construct validity of selfreport questionnaires for patients with pelvic girdle pain. Phys Ther 2012;92:111-23.

12. Fairbank JC, Couper J, Davies JB, O'Brein JP. The Oswestry low back pain disability questionnaire. Physiotherapy 1980;66:271-3.

13. Yakut E, Duger T, Oksuz C et al. Validation of the Turkish version of the Oswestry Disability Index for patients with low back pain. Spine (Phila Pa 1976) 2004;29:581-5.

14. Baum FE, Cooke RD. Community-health needs assessment: use of the Nottingham health profile in an Australian study. Med J Aust 1989;150:581-90.

15. Kucukdeveci AA, McKenna SP, Kutlay, Gursel Y, Whalley D, Arasıl T. The development and psychometric assessment of the Turkish version of the Nottingham Health Profile. Int J Rehabil Res 2000;23: 31-8.

16. Beaton DE, Bombardier C, Guillemin F. Guidelines for the process of cross-cultural adaptation of self-report measures. Spine 2000;25: 3186-91.

17. Feise RJ, Michael Menke J. Functional rating index: a new valid and reliable instrument to measure the magnitude of clinical change in spinal conditions. Spine (Phila Pa 1976) 2001;26: 7886

18. Portney LG, Watkins MP Foundation of clinical research: applications to practice. Boston: Prentice Hall; 2000 